* This is the accepted manuscript of a paper published in Marine Policy. The formatted version may be accessed at https://doi.org/10.1016/j.marpol.2018.04.010.

This paper is available under a CC-BY-NC-ND license.

\title{
Building trust among marine protected area managers and community members through scientific research: Insights from the Ningaloo Marine Park, Australia
}

C. Cvitanovic ${ }^{a}$

E.I. van Putten ${ }^{a, b}$

A.J. Hobdaya,b

M. Mackay a,c

R. Kelly ${ }^{a, d}$

J. McDonald ${ }^{\mathrm{a}, \mathrm{e}}$

K.Waples ${ }^{\mathrm{f} g}$

P. Barnes ${ }^{h}$

a Centre for Marine Socioecology, University of Tasmania, Battery Point, Tasmania 7004, Australia

b Oceans and Atmosphere, CSIRO, Hobart, Tasmania 7001, Australia

c Tasmanian School of Business and Economics, University of Tasmania, Sandy Bay, Tasmania 7004, Australia

d Institute for Marine and Antarctic Studies, University of Tasmania, Battery Point, Tasmania 7004, Australia

e Faculty of Law, University of Tasmania, Sandy Bay, Tasmania 7004, Australia

f Marine Science Program, Department of Biodiversity, Conservation and Attractions, Kensington, Western Australia, Australia

g Western Australian Marine Science Institution, Crawley, Western Australia, Australia

$\mathrm{h}$ Department of Biodiversity, Conservation and Attractions, Exmouth, Western Australia, Australia

\section{Abstract}

The success of participatory marine governance arrangements is influenced by the levels of trust that exist between decision-makers and diverse stakeholder groups within the community. While the benefits of high levels of trust among these groups is well established, specific approaches to building trust remain largely unknown. The aim of this study is to understand the extent to which scientific research programs can enhance trust among marine 
protected area (MPA) managers and community members via an evaluation of the Ningaloo Research Program - a large-scale program of marine research in the Ningaloo Marine Park. Results from a survey of 125 local residents show that community members along the Ningaloo coast believe that scientific research is important for the management of the marine park, and strongly support government investment in scientific research in the region. Results also suggest that science undertaken through the Ningaloo Research Program has increased the extent to which community members trust local managers, which study participants believe has led to improved social and environmental outcomes in the region. Finally, additional opportunities are identified to maintain and further enhance trust between community members and MPA managers, via targeted communication and engagement programs that account for different personality 'types'. In particular, the establishment of citizen science programs might further build trust. These results suggest that scientific research could be used as a means to increase trust among decision-makers and community members when coupled with an effective communication and outreach program, thus enhancing the success of participatory marine governance arrangements.

\section{Introduction}

The conservation and sustainable management of marine resources remains a significant challenge (e.g. [36]). Embedded within large, complex socio-ecological systems and facing uncertain and unpredictable threats such as those associated with climate change and population growth [35], it has become increasingly apparent that achieving successful management outcomes depends on stakeholder support for, and participation in, diverse governance activities [45]. As a result, there has been a shift away from traditional hierarchical governance systems in relation to marine resource management, towards more inclusive and participatory approaches that claim to ac- knowledge and integrate the interests of all stakeholders. Underpinning the success of such governance arrangements is the level of trust that exists between local resource managers and the diverse stakeholders that share an interest in the resource being governed [39].

The benefits associated with high levels of trust among resource managers and their stakeholders are well established. For example, Turner et al. [52] found that high levels of trust increases public perceptions regarding the legitimacy of management decisions. Benefits associated with legitimacy include increased levels of voluntary compliance by stakeholders, which in turn, reduces transaction costs, as fewer resources are required than for more common interventions such as compliance and enforcement $[3,39]$. Similarly, Diedrich et al. [19] showed that trust in leadership positively affected the perceived benefits that community members derived from marine protected areas (MPAs) in the Philippines, in turn helping to address potential problems associated with equity and conflict in the region, and leading to greater levels of collective action. Gilmour et al. [23] also found that trust is a key factor underpinning knowledge exchange among decision-makers and community members in different coastal settings, which increases the likelihood that different types of knowledge (e.g., local knowledge, traditional knowledge, experiential knowledge, etc.) will be integrated into decision-making processes. This is believed to enhance the success of complex decision-making 
processes, because it takes into account various worldviews and perspectives and ensures that the knowledge used is at a scale most relevant to the challenge at hand $[13,9]$.

Despite widespread acceptance regarding the importance of trust in relation to the governance of marine resources, specific approaches to building and maintaining trust between MPA managers and diverse stakeholders within their community remain largely unknown [6]. Thus, strategies that can lead to the development of trust among marine decision-makers and community members to enhance the conservation and sustainable management of marine resources are needed. This study contributes towards filling this gap, by exploring the extent to which large-scale scientific research programs can foster the development of trust among marine decision-makers and community members. This is achieved via a case study of the Ningaloo Research Program (NRP) in Western Australia; a ten-year research program valued at \$AUD36million designed to generate new scientific knowledge about the Ningaloo Marine Park and surrounding region. In doing so this study develops upon the results of Cvitanovic et al. [15], which found that local Ningaloo Marine Park managers felt that local community groups had greater trust in managers and management actions because of the NRP. That study, however, did not assess community perceptions relating to trust and thus the extent to which the NRP built trust among community members and local managers could not be determined.

In undertaking this evaluation of the NRP there are three primary objectives. These are to evaluate the perceptions of the local community regarding (i) the management of the Ningaloo Marine Park, (ii) the role and importance of science for managing the Ningaloo Marine Park, and (iii) the extent to which scientific research undertaken through the NRP has built trust between local decision-makers and community members, and whether this has led to improved collective action, social cohesion or communication among the groups. Using this data, in combination with the demographic information provided by each study participant, a typology of 'personality types' among community members is developed to inform the design and implementation of future communication and engagement activities in the region (sensu [26]).

\section{Methods}

\section{Study site}

Ningaloo Reef is Australia's largest fringing coral reef, extending across $300 \mathrm{~km}$ of coast in Western Australia, Australia. The area is a global biodiversity hotspot which was formally recognised in 1987 through the creation of the Ningaloo Marine Park (NMP). In 2004, the NMP was extended to cover the entire Ningaloo Reef Area and in 2011, the Ningaloo Coast was also inscribed on the World Heritage List in recognition of the 'outstanding universal value of the area's diverse and abundant marine life, its amazing cave fauna and the spectacular contrast between the colourful underwater scenery and the arid and rugged land of the Cape Range'. The Ningaloo region is also a key service point for offshore oil and gas development and exploration along the west Australian coastline, and a premier tourist destination. 
Two communities are located directly adjacent to the marine park. The largest, Exmouth, has a permanent population of approximately 2600 residents, and marks the northern most end of the NMP. The Exmouth community is heavily reliant on marine-based tourism, with the local population growing in excess of 6000 people during peak tourist season. The other permanent settlement, Coral Bay, is located approximately $150 \mathrm{~km}$ south of Exmouth with a permanent population of approximately 200 residents. Similarly to Exmouth, the economy of Coral Bay is also largely sustained by the tourism sector. Along the remainder of the NMP are several pastoral leases that are managed by long-term lessees with grazing rights, however, many of these also accommodate tourists via camp sites adjacent to the marine park.

The NMP, and the adjacent Cape Range National Park, are managed by the Western Australian Government Department of Biodiversity, Conservation and Attractions. The marine park is managed in accordance with State Legislation (CALM Act 1984) and the associated Management Plan for the Ningaloo Marine Park and Muiron Islands Marine Management Area 2005 - 2015. Despite community consultation during the development of the management plan and its implementation, an assessment of community perceptions in relation to the World Heritage Nomination of the region demonstrated a lack of trust between the local community and management authorities, resulting from perceived political and social concerns, and claims of misinformation and unfairness [29]. Thus, while it was not possible to undertake a baseline assessment of trust between community members and local marine park managers in the Ningaloo region for the purpose of this study, this recent evidence suggests that there was a lack of trust in the Ningaloo region. Ningaloo therefore represents an ideal location to explore the extent to which scientific research programs are a factor that can contribute to building trust among diverse community groups and decision-makers, ultimately to the benefit of the MPA conservation outcomes.

\section{Survey design and administration}

A combination of qualitative and quantitative research methods were used to address the study aims. Firstly, a qualitative scoping study which involved semi-structured interviews was undertaken with ten community members to understand their broad perceptions regarding the three study aims. These participants were sourced from a broad spectrum of community groups involved in diverse activities relating to the Ningaloo Marine Park, such as commercial fishers, recreational fishers, non-government organisations, the tourism sector, and the education sector. By ensuring a diversity of participants in this manner, the results capture a range of experiences and opinions in relation to the Ningaloo Marine Park for developing the final quantitative survey [32].

Open-ended questions were considered advantageous for the scoping study as they provided the research team with the means to explore ideas and opinions in greater depth. This helped to ensure that the final quantitative survey was comprehensive to the issues raised by the diverse community members who participated in the scoping study [8]. The questions that formed the basis of the scoping study were designed to directly explore the perceptions of the local community regarding the three focal aims of this study. The scoping study was not aimed at assessing any other scientific successes or failures relating the NRP program aside from those 
relating to the development of trust. Following completion of each interview, the scoping responses were transcribed by the same author undertaking the interviews (CC) and converted into a series of statements for inclusion in the quantitative survey (following [12]).

The quantitative survey was developed to address the study aims as efficiently as possible within each of the scoping categories to maximise participation from community members in this study (i.e. the resource requirements needed for a qualitative study would have severely restricted the overall sample size). As such, all questions were presented to participants as a statement (which was developed from the scoping study - statements are listed in the first column of tables), and respondents were asked to indicate how strongly they agreed or disagreed with each statement on a 10-point Likert scale. Using this approach, a score of 1 indicated that the participant strongly disagreed with the statement, while a score of 10 meant that the participant strongly agreed with the statement. Using this scale there is no mid-point, thus a score of 5 indicated that the participant slightly disagreed with the statement, while a score of 6 indicated that the participant slightly agreed with the statement [8]. Prior to implementation, the quantitative survey was pre-tested on a small group of community members for ambiguity and refined accordingly.

The survey was conducted in-situ along the Ningaloo coast, in the two major settlements of Exmouth and Coral Bay in September 2016 by three interviewers (authors CC, MM and RK). To ensure a random sample and to maximise the opportunity for community members to participate in the survey, the three interviewers spent eight days in central locations (e.g. outside shopping centres, boat ramps, etc.) in both Exmouth and Coral Bay. As part of the survey, a range of demo- graphic variables were collected for each participant; location (Coral Bay or Exmouth), length of residency in the region, year of birth (which was later converted to generation), gender and highest level of education completed (year 10, year 12, Diploma of Education, Bachelor Degree or Advanced university degree).

\section{Data analysis}

In total, 137 community members completed the quantitative survey - with care taken to ensure that only permanent residents of the region were surveyed. For the purpose of this study, permanent residents were defined as those who lived in the region as their primary place of residence, thus excluding tourists and those who primarily reside elsewhere in Western Australia but annually visited the Ningaloo region for an extended period. However, after initial inspection of the data, responses from 12 participants were removed (because they either did not complete the survey correctly or because their answers suggested they did not correctly interpret the question (e.g. they may have given the same score for all answers)). This resulted in a final sample size of 125 participants: 85 from Exmouth and 40 from Coral Bay. The final sample contained a slightly higher proportion of females ( $58 \%$ of the sample), and the average age of the survey respondents was 42 which corresponds well with a relatively young demographic in both locations (median age of 37 in Exmouth and 31 in Coral Bay, Australian Bureau of Statistics). 
Data were entered in Excel, and the software package ' $R$ ' (version 3.2.0) was used for the data analysis. The full data set was firstly analysed to assess the residents' perceptions about the management of the NMP, the importance of science for managing the NMP, and the extent to which the Ningaloo Research Program built trust between local decision-makers and community members, and whether this has led to improved collective action, social cohesion or communication. In doing so it is important to acknowledge ongoing debate within the scientific literature as to whether Likert data should be considered as ordinal or interval, and the associated implications for analyses and reporting. This discussion has largely arisen due to the potential for ambiguity regarding the distance between numerical responses and whether they are interpreted equally by respondents [25]. To help address this, each study participant was given linguistic qualifiers prior to the commencement of the survey (following [11]).

Furthermore, in the results section, both the ordinal and interval results are presented (i.e. means and modes) for each statement (the distribution is shown in Appendix A).

Tests for differences in community member perceptions of the NMP; and the extent to which the Ningaloo Research Program built trust among decision-makers and community members, were carried out across several demographic characteristics (education, location, length of residency in the region, generation, and gender). A Kruskal- Wallis test was used to determine the statistical significance of the difference ( $R$ routine Kruskal test). Kruskal-Wallis tests are nonparametric rank-based tests, allowing for the comparison of scores across continuous variables for more than two groups simultaneously. A significance level of 0.05 was assumed to indicate statistically significant differences.

In addition to the above descriptive statistics, a typology of residents was developed to inform future communication and engagement activities in the region. This involved typifying and grouping survey participants along two axes based on their survey responses: (1) their confidence in the management of the marine park, and (2) their level of engagement in the management of the marine park (following [26]). We used data for all 137 respondents to develop the typology as there was no missing data along the two axes mentioned above. For the statistical tests of difference for demographic and trust variables the population averages were used to replace missing values. A multinomial logit analysis (using the mlogit and nnet procedures in R) was used to characterise the different respondents according to their perception of science, level of trust, collective action and cooperation, information and communication, and social cohesion.

\section{Results}

Community perceptions regarding the management of the Ningaloo Marine Park, and the role of science for informing management

Results show that the conservation and sustainable management of the NMP is important to community members within the Ningaloo region, and that in general, residents are confident that the marine park is well managed (Table 1). Local community members also have a strong understanding of, and support for, the current rules and regulations associated with the NMP, 
believing that they have fair access to undertake the activities that they enjoy. However, results show that community members do not feel actively engaged in the management of the NMP, and indicate that they would like to have more opportunities to provide input into the management and conservation of the area (Table 1).

\section{Table 1}

Perceptions of Ningaloo community members $(n=125)$ regarding the current management of the NMP. Scores are based on a Likert scale between 1 (re- presenting strongly disagreed) and 10 (representing strongly agreed).

\begin{tabular}{|l|l|l|}
\hline & Mean & Mode \\
\hline I feel confident that the Ningaloo Marine Park is well managed. & 7.3 & 8 \\
\hline $\begin{array}{l}\text { The conservation and sustainable management of the Ningaloo Marine Park is } \\
\text { important to me. }\end{array}$ & 9.1 & 10 \\
\hline $\begin{array}{l}\text { I have a strong understanding of the current rules and regulations associated } \\
\text { with the Ningaloo Marine Park. }\end{array}$ & 8.1 & 10 \\
\hline $\begin{array}{l}\text { I support the current rules and regulations associated with the Ningaloo Marine } \\
\text { Park. }\end{array}$ & 8.5 & 10 \\
\hline I have fair access to the Ningaloo Marine Park for the activities I enjoy. & 9.0 & 10 \\
\hline $\begin{array}{l}\text { I feel engaged in the management of the Ningaloo Marine Park, and have } \\
\text { opportunities to contribute my views to the way it is managed. }\end{array}$ & 5.6 & 1 \\
\hline $\begin{array}{l}\text { I would like more opportunities to provide input to the management and } \\
\text { conservation strategies for the Ningaloo Marine Park. }\end{array}$ & 7.1 & 10 \\
\hline
\end{tabular}

Results also show that community members along the Ningaloo coast believe that scientific research is important for the management of the NMP, and that it is important on a personal level to community members that management decisions are based on scientific evidence (Table 2). To this end, the local community also strongly agreed that the government should invest in scientific research in relation to the NMP, and that they had already noticed an increase in research in the area over the past decade (Table 2).

\section{Table 2}

Perceptions of Ningaloo community members $(n=125)$ regarding the importance of science for managing the NMP. Scores are based on a Likert scale between 1 (representing strongly disagreed) and 10 (representing strongly agreed).

\begin{tabular}{|l|l|l|}
\hline $\begin{array}{l}\text { Scientific research is important for the management of the Ningaloo Marine } \\
\text { Park. }\end{array}$ & Mean & Mode \\
\hline $\begin{array}{l}\text { I have noticed an increase in the amount of scientific research undertaken in } \\
\text { the Ningaloo Marine Park over the last 10 years. }\end{array}$ & 7.4 & 10 \\
\hline $\begin{array}{l}\text { I believe that the government should invest in scientific research that helps } \\
\text { inform management of the Ningaloo Marine Park. }\end{array}$ & 8.8 & 10 \\
\hline $\begin{array}{l}\text { It is important to me that the management of the Ningaloo Marine Park is } \\
\text { based on scientific evidence. }\end{array}$ & 8.6 & 10 \\
\hline
\end{tabular}


Some statistically-significant demographic differences in participant's perceptions of management and science were also evident. Firstly, results show that females felt more strongly that they have fair access to the NMP to undertake the activities that they enjoy (Kruskal Wallis $p=0.022$ ), and felt more engaged in the management of the NMP (Kruskal Wallis $p=0.003$ ). The results also found that participants with lower education levels wanted more opportunities to pro- vide input to the management than those with higher levels of education (Kruskal Wallis $p=0.059$ ). Next, results show that participants who live in Exmouth place more importance on scientific evidence being used to manage the park than those living in Coral Bay (Kruskal Wallis $p=0.014$ ). Finally, and perhaps unsurprisingly, participants who have lived in the area longer have noticed the increase in scientific research undertaken in the region more-so than those who have moved into the region more recently (Kruskal Wallis $p=$ 0.004).

\section{The influence of scientific research on levels of trust, collective action, cohesion and communication among decision-makers and community members}

The Ningaloo Research Program has had a positive influence on the levels of trust that exist between local decision-makers and community members in the Ningaloo region of Western Australia (Table 3). Specifically, the results show that participants in this study trust the marine park managers to make better decisions in relation to the management of the NMP because of the science undertaken in the NMP (Table 3). The results also suggest that local community members trust the decision-makers to use the science ethically, and not to promote a political agenda. Results of the Kruskal-Wallis test showed that females in particular scored higher on these two dimensions of trust than males (making better decisions on the basis of science $p=$ 0.009 and using the science ethically $p=0.000$ ). Finally, participants in this study believed that increased trust among the local community and decision-makers, as a result of scientific research undertaken through the Ningaloo Re- search Program, has led to improved environmental and social out- comes for the region (Table 3).

In regards to collective action, the study participants would like more opportunities to be involved in the scientific research undertaken in the NMP (Table 4). In particular, there is a desire among the com- munity for the establishment of community-based research programs in which they can actively participate. Once again, the results of the Kruskal-Wallis test revealed significant differences among different demographics in relation to collective action. Specifically, those who had completed higher levels of education (Kruskal Wallis $p=0.049$ ) felt that they have had more opportunities to engage in the scientific research undertaken in the NMP. Younger people ( $<53$ years of age) indicated they would like to become more involved (Kruskal Wallis $p=0.019$ ). This is also reflected in the fact that younger people and those with higher education were more likely to have attended a public science forum in Exmouth in relation to the scientific research under- taken in the NMP. Most significantly, whilst people who had been in the area for longer than 10 years had participated more actively in scientific research, they were less interested in becoming more involved or in the establishment of a community-based science program. 
Table 3

Perceptions of Ningaloo community members $(n=125)$ regarding the extent to which the Ningaloo Research Program has built trust among local decision-makers and community members. Scores are based on a Likert scale between 1 (representing strongly disagreed) and 10 (representing strongly agreed).

\begin{tabular}{|l|l|l|}
\hline & Mean & Mode \\
\hline $\begin{array}{l}\text { I trust the marine park managers to make better decisions in relation to the } \\
\text { management of the Ningaloo Marine Park because of the science undertaken. }\end{array}$ & 7.6 & 10 \\
\hline $\begin{array}{l}\text { I trust the marine park managers to use the scientific information responsibly } \\
\text { and ethically and not to impose a political agenda. }\end{array}$ & 7.4 & 10 \\
\hline $\begin{array}{l}\text { The scientific research undertaken in the Ningaloo Marine Park has led to } \\
\text { greater trust among the local community and marine park managers. }\end{array}$ & 6.7 & 8 \\
\hline $\begin{array}{l}\text { Increased trust between the local marine managers and community have led to } \\
\text { better environmental outcomes for the management of the Ningaloo Marine } \\
\text { Park, such as greater acceptance of the local rules and regulations. }\end{array}$ & 7.3 & 8 \\
\hline $\begin{array}{l}\text { Increased trust between the local marine managers and community have led to } \\
\text { better social outcomes for the management of the Ningaloo Marine Park. }\end{array}$ & 6.9 & 8 \\
\hline
\end{tabular}

When asked whether the Ningaloo Research Program has improved social cohesion among community members and decision-makers, participants suggested that the research undertaken in the marine park has led to a greater awareness of the authorities responsible for managing the NMP by the community (Table 4). They also agreed that scientific research undertaken in the marine park has resulted in more community-led conservation initiatives. However, the level of aware- ness was significantly higher in Exmouth than in Coral Bay (Kruskal Wallis $p=0.040$ ). Also, older people felt more strongly that scientific research undertaken in the marine park has led to community-led initiatives to improve its management (Kruskal Wallis $p=0.049$ ). Fe- males felt more strongly that science had provided them with the opportunity to meet, interact with and talk to those responsible for the management of the Ningaloo Marine Park (Kruskal Wallis $p=0.044$ ). The people who had lived in the area for longer felt less strongly that the science undertaken in the marine park had reduced conflict between its various users (Kruskal Wallis $p=0.037$ ).

Results also suggest that communication and information sharing among the local decisionmakers and community members did not in-crease as a result of the Ningaloo Research Program. For example, the results suggest that community members did not have a strong under-standing of the scientific research undertaken in the marine park, or the ways in which it is used to influence management (Table 4). Participants did indicate, however, that they would like to know more about the scientific research undertaken in the marine park, and would like local marine park managers to communicate the results of scientific research undertaken in the NMP more effectively (Table 4). They sug- gested that this could be achieved through public events such as town meetings that could allow for two-way discussion of scientific results and their management implications between community members and local decision-makers (Table 4). There was no statistical difference in terms of communication needs between genders or location but there were some generational and educational differences. Younger people had lower levels of understanding of how science undertaken in the park could be used to inform 


\section{Table 4}

Perceptions of Ningaloo community members $(n=125)$ regarding the extent to which the Ningaloo Research Program improved collective action, social cohesion and communication among local decisionmakers and community members. Scores are based on a Likert scale between 1 (representing strongly disagreed) and 10 (representing strongly agreed).

\begin{tabular}{|c|c|c|}
\hline & Mean & Mode \\
\hline \multicolumn{3}{|l|}{ Collective Action } \\
\hline $\begin{array}{l}\text { I have actively participated in scientific research undertaken in the Ningaloo Marine } \\
\text { Park. }\end{array}$ & 5.7 & 10 \\
\hline $\begin{array}{l}\text { I have had opportunities to engage in the scientific research undertaken in the } \\
\text { Ningal oo Marine Park. }\end{array}$ & 6.0 & 10 \\
\hline $\begin{array}{l}\text { I would like more opportunities to be involved in the scientific research undertaken } \\
\text { in the Ningaloo Marine Park. }\end{array}$ & 7.3 & 10 \\
\hline $\begin{array}{l}\text { I would like the local marine park managers to establish a community-based science } \\
\text { program that I can actively participate in. }\end{array}$ & 7.3 & 10 \\
\hline \multicolumn{3}{|l|}{ Social Cohesion } \\
\hline $\begin{array}{l}\text { I am aware of the authorities responsible for managing the Ningaloo Marine Park } \\
\text { because of the science undertaken in the marine park. }\end{array}$ & 8.0 & 10 \\
\hline $\begin{array}{l}\text { The scientific research undertaken in the Ningaloo Marine Park has led to a stronger } \\
\text { relationship between the local community and marine park managers. }\end{array}$ & 5.9 & 5 \\
\hline $\begin{array}{l}\text { The scientific research undertaken in the marine park has led to community-led } \\
\text { initiatives to improve its management. }\end{array}$ & 6.5 & 6 \\
\hline $\begin{array}{l}\text { The science undertaken in the marine park has reduced conflict between its various } \\
\text { users. }\end{array}$ & 5.9 & 7 \\
\hline $\begin{array}{l}\text { The science undertaken in the Ningaloo Marine Park has reduced conflict between } \\
\text { the local community and those responsible for managing the marine park. }\end{array}$ & 5.8 & 6 \\
\hline $\begin{array}{l}\text { Science has provided me with the opportunity to meet, interact and talk to those } \\
\text { responsible for the management of the Ningaloo Marine Park. }\end{array}$ & 5.8 & 10 \\
\hline \multicolumn{3}{|l|}{ Information and Communication } \\
\hline $\begin{array}{l}\text { I have a strong awareness of the scientific research undertaken in the Ningaloo } \\
\text { Marine Park. }\end{array}$ & 5.7 & 7 \\
\hline $\begin{array}{l}\text { I have a strong understanding of how the scientific research undertaken in the } \\
\text { Ningaloo Marine Park influences the way the park is managed. }\end{array}$ & 5.9 & 6 \\
\hline $\begin{array}{l}\text { I would like to know more about the scientific research that is undertaken in the } \\
\text { Ningaloo Marine Park. }\end{array}$ & 7.7 & 10 \\
\hline $\begin{array}{l}\text { The results of the science undertaken in the Ningaloo Marine Park are made publicly } \\
\text { available. }\end{array}$ & 6.0 & 6 \\
\hline $\begin{array}{l}\text { I have attended a public science forum in Exmouth in relation to the scientific } \\
\text { research undertaken in the Ningaloo Marine Park. }\end{array}$ & 4.0 & 1 \\
\hline $\begin{array}{l}\text { I would like to attend public events that highlight the scientific research undertaken } \\
\text { in the Ningaloo Marine Park. }\end{array}$ & 7.1 & 10 \\
\hline $\begin{array}{l}\text { Local marine park managers have made an effort to communicate the results of } \\
\text { scientific research undertaken in the Ningaloo marine Park to the local community }\end{array}$ & 5.5 & 5 \\
\hline $\begin{array}{l}\text { I would like the local marine park managers to communicate the results of scientific } \\
\text { research undertaken in the Ningaloo Marine Park to the local community. }\end{array}$ & 8.3 & 10 \\
\hline
\end{tabular}


management (Kruskal Wallis $p=0.035$ ) and were more inclined to attend public events (Kruskal Wallis $p=0.017)$. Participants who had higher levels of education also had a stronger understanding of the science (Kruskal Wallis $p=0.081$ ) and were more likely to have attended science events in the past (Kruskal Wallis $p=0.053$ ).

Finally, analysis showed that some correlations were evident among the dimensions of trust, collective action, social cohesion and communication (i.e. statements in Tables 3, 4). Most notably, all five dimensions of trust and six dimensions of social cohesion are internally correlated (i.e. if one is high then the other one is too). For instance, if respondents indicated they trust the marine park managers to use the scientific information responsibly and ethically and not to impose a political agenda, then they were also likely to have indicated a high value for 'The scientific research undertaken in the NMP has led to a stronger relationship between the local community and marine park managers'. In contrast, the different dimensions of communication and information sharing were not internally correlated.

\section{Developing a resident typology}

While in general the results suggest that the scientific research undertaken through the Ningaloo Research Program has built trust in decision-makers by many community members, the levels of trust were not consistent among all segments of community members. Thus, to understand how it varied across different 'types' of community members, participant responses were typified along two axes: i) their confidence in the management of the park, and ii) their level of engagement in the management of the marine park. Doing so identified three 'types' of community members in the Ningaloo region.

There was a group of residents who had high confidence in the management of the park and who felt engaged in the management of the NMP, and had opportunities to contribute their views (Fig. 1). This was the largest group $(n=62)$, labelled the 'engaged optimists'. The second group in the typology were the 'disengaged pessimists', who had low confidence in the management of the park and did not feel engaged $(n=32)$. In between these groups were 43 people who had high confidence but did not feel engaged, who are termed 'disengaged optimists'. These three types of respondents significantly differed on all dimensions of trust, however, were not statistically different with regard to their demographic characteristics.

Both the 'engaged optimists' and 'disengaged optimists' value scientific research, and indeed, it was on these 'types' of community members that science has the most significant impact in terms of building trust. Therefore, the challenge for decision-makers in the Ningaloo region is to understand how to improve trust among the 'disengaged pessimists' so as to achieve better social and environmental outcomes. Based on the results of this study, it is clear that scientific research alone cannot increase the extent to which community members who are 'disengaged pessimists' trust decision-makers, and other trust building approaches are required. 


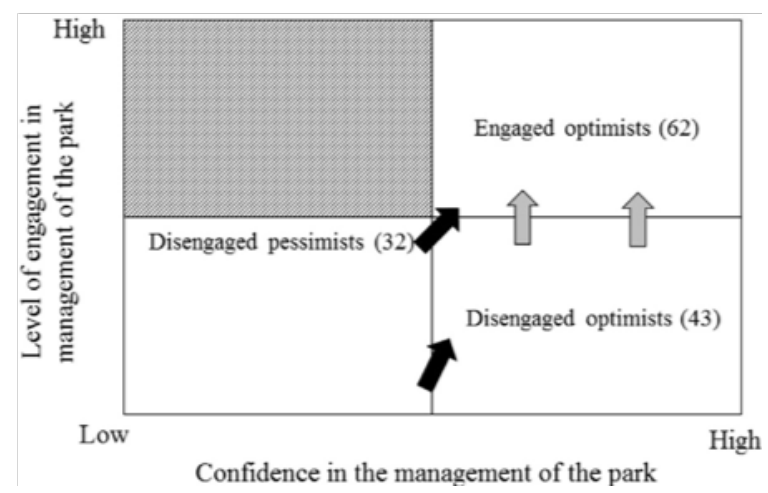

Fig. 1. Conceptual diagram showing the three' types' of residents identified according to how engaged and confident they were in management of the Ningaloo Marine Park. The hatched area indicates there were no observations of this group in the study (i.e. there were no residents who had low confidence but were highly engaged). The arrows indicate the direction the decision-makers might want to move people in the bottom two groups to achieve higher engagement and confidence levels.

\section{Discussion}

Marine governance can be enhanced by high levels of trust among decision-makers and diverse stakeholder groups within the community. However, while the benefits of trust are known, the strategies for building trust among MPA managers and community members remain largely unknown. To help address this gap, this study assessed the extent to which scientific research can improve trust in decision-makers by diverse community members, via a case study of the Ningaloo Research Program. Results suggest that the Ningaloo Research Program has led to enhanced community trust in local MPA managers, which study participants (i.e. community members) believe has led to improved social and environmental outcomes in the region. This study also identified additional opportunities to maintain and further enhance trust between community members and decision-makers in the region, via improved and targeted communication and engagement programs that account for different personality 'types' in the region. Here, these findings are discussed, with a view of identifying strategies for maximising the extent to which scientific research programs can be utilised as a trust building initiative.

\section{Implications for the management of the Ningaloo Marine Park}

The increase in trust in MPA managers by community members resulting from the Ningaloo Research Program has important implications for the management of the NMP. As shown by Turner et al. [52], high levels of trust underpin public perceptions regarding the legitimacy of management decisions, where legitimacy is defined as the right of a governing body to rule and the recognition of this right among those being governed [53]. Consequently, higher levels of legitimacy are associated with greater acceptance of management decisions by community members, and lead to improved environmental outcomes. While it was not within the scope of this study to explore the extent to which increased trust has led to tangible environmental outcomes, community members did perceive that increased levels of trust had led to improved social and environmental outcomes throughout the Ningaloo region. Furthermore, public perceptions of trust and legitimacy are also known to increase levels of voluntary compliance by resource users (e.g. $[28,42]$ ). Given the significant financial costs of more traditional modes 
of compliance, such as enforcement in large MPAs, financial resources may be better invested in improving governance, local capacity building, participation, and outreach programs to support conservation and management efforts [2].

High levels of trust can also facilitate collective action and social cohesion among diverse stakeholder groups, giving individuals the confidence to invest in activities knowing that others will do the same [40,7]. While the results do not suggest that the Ningaloo Research Program had increased levels of collective action or social cohesion among decision-makers and community members per se, these results are positive in that they suggest that community members would like more opportunities to be engaged in the management of the NMP, as well as with the science undertaken in the marine park. It is expected that improved engagement of community members in management and science activities can reinforce and further enhance the trust created through the Ningaloo Research program, and the associated benefits.

\section{Strategies to build and maintain trust among MPA managers and community members}

One approach identified though this study to increase the extent to which community members participate more actively in scientific research in the marine park is through the establishment of citizen science programs. In its broadest sense, citizen science is described as a partnership between the public and professional scientists (such as those leading the Ningaloo Research Program) to address questions and issues of common concern [44], and is touted as an effective mechanism to promote networks for collaborative decision-making that can enhance outcomes for science and management [17]. It has also been suggested that citizen science can foster greater public involvement in environmental policy processes [54] by increasing communication and knowledge-sharing within and across resource management stakeholder groups [43]. Further, and in addition to benefits associated with trust and engagement, evidence also suggests that citizen science can raise public awareness about the marine environment $[33,5]$ and encourage the appreciation of conservation initiatives among diverse community groups [22], thereby improving environmental stewardship among community members $[24,30]$. Results suggest, that in the case of the NMP, citizen science projects could be a particularly valuable means to target youth involvement. Younger individuals were typically less engaged in management, but had a very strong desire to increase their engagement.

While in principle citizen science projects are considered relatively quick and easy to establish, their success is ultimately dependent on adequate planning and long-term funding and support from agencies to ensure community members do not become disenchanted and lose trust when well-intentioned but inadequately supported projects fail. This can be particularly important in less-populated communities such as Exmouth and Coral Bay, as there are only small numbers of volunteers available to draw upon. Thus, care is needed to ensure that citizen science programs are designed appropriately to foster ongoing participation of community members while also ensuring that outputs are meaningful to management. Evidence of successful and well-designed citizen science programs are already evident within the Ningaloo region, for example, via the Ningaloo Turtle Program - a long-term volunteer turtle monitoring program established by local decision-makers, environmental groups and researchers to inform the management of turtles in the region [55]. By drawing on the lessons learnt through the 
highly successful Ningaloo Turtle Program, local decision-makers can make informed decisions about the best ways to design and implement new and successful citizen science programs in the region.

The results of this study also highlight that in addition to becoming more involved in science and management relating to the marine park, community members want decision-makers to communicate the results of scientific research more effectively with them. Indeed, identifying more effective methods of communicating science to diverse communities has previously been recognised as a critical research need relating to the management of MPAs [14], as traditional modes of communication fail to account for the full diversity of worldviews within diverse communities [47]. In order to enhance the communication of science in the Ningaloo region to local communities, decision-makers will need to utilise a range of outreach methods that specifically target different groups within the community, and allow for two-way discussion of results. For example, results suggest that com- munity members would like to attend public forums where the results of scientific research and their implications are presented and then discussed with community members (e.g. [24]). Interestingly, however, numerous public forums were held in the region as part of the Ningaloo Research Program for this purpose, with anecdotal evidence from local decision-makers suggesting that they were sometimes not wellattended by community members. This may suggest that the ways in which these forums were advertised to the community were not sufficiently targeted to ensure high levels of participation, and local decision-makers may need to develop new tailored approaches to promoting public events. Social media may be useful in this regard $[38,48]$ given its participatory, immediate and engaging nature [1], especially among younger generations who do not typically engage with more traditional modes of media. Social media may be particularly useful to communicate to the public in relation to the management of marine parks globally given the inherent charismatic nature of marine species and systems.

Improved and sustained communication and engagement with community members will also be critical for maintaining and further increasing levels of trust among the two groups. For example, trust is not a static process and while it can take considerable time, resources and effort to develop - it can be easily and quickly lost and potentially never recover [30]. In this way, the concept of trust is similar to that of reputational risk in the private sector, whereby companies continually invest in 'public good' to maintain levels of support among local constituents [21]. As has been shown in relation to the business sector, maintaining high levels of public support requires ongoing communication, engagement and participation among the company and com- munity members $[18,20]$. Likewise, natural resource decision-makers should ensure that communication channels and engagement efforts with community members are sustained and maintained, even following the completion of scientific research programs such as the NRP.

\section{Future research}

While the results of this study suggest that scientific research can increase trust among decision-makers and community members, a small group of individuals who were not confident or engaged in the management of the NMP, and who did not value science, were also 
identified. A group such as this that is characterised as 'disengaged pessimists' can be wrongly assumed to have similar demographics, such as being older [10]. In the current study, however, the disengaged pessimists were represented across all demographic groups. Irrespective, it is unlikely that trust can be built with this 'type' of resident through scientific research programs. Rather, decision-makers will be required to find other ways to engage with these community members to ensure that they comply with relevant laws and policies and act in the best interests of the marine park to ensure its long-term sustainability.

To do so decision-makers should first seek to understand the cultural models of these individuals [41,51]. In this respect, Thompson [50] defines cultural models as imaginative structures that people use to evaluate experiences, interpret observations, form judgements, make inferences, and make decisions. In this way an individual's cultural model underpins their worldviews and their motivations for taking particular actions [46]. Thus, by identifying and understanding the shared cultural models of individuals that this study has characterised as 'disengaged pessimist', local MPA managers can develop communication and outreach efforts based on shared values so as to foster the meaningful participation of these individuals in local MPA management initiatives while minimising the likelihood of conflict [16]. Understanding the cultural models of community members throughout the Ningaloo region, however, was outside of the scope of this study and warrants future investigation. Further, any future study seeking to explore the ways in which trust can be enhanced among MPA managers and community members could incorporate measures of cultural models within their study design at the onset.

Further, understanding the cultural models of community members, and their underpinning drivers, may assist local MPA managers to develop behavioural incentives, or "nudges" [49], to increase participation and compliance among all community members, including those labelled as 'disengaged pessimist'. This would be made possible as it would allow local managers to target the more subtle and subconscious behavioural drivers of different resident 'types' to elicit pro-social behaviours and decisions [37], in a cost-effective manner [4]. Indeed, behavioural nudges have already been used successfully in a range of sectors and settings such as the medical industry to increase surgery uptake [34,4], and in private enterprise to increase business productivity [27]. The use of nudges could similarly be applied in conservation settings (e.g. MPA management) to increase compliance among stakeholders who are less engaged and have less confidence in local management efforts. However, further research is needed to fully understand the potential added value of 'nudges' when used in com- bination with other approaches to influencing behaviour such as regulation, education, and economic incentives. Furthermore, the development and value assessment of nudges should be informed by understanding the personality types and cultural models of community members.

Finally, while the results of this study have demonstrated that scientific research can improve trust among decision-makers and com- munity members, it is important to note that these results are context specific to the Ningaloo region of Western Australia. Thus, further studies are needed to understand how scientific research can be harnessed in other regions and contexts to improve the relationship among decision-makers and community members. Such future studies would benefit from the inclusion of qualitative interviews with community 
members to develop a more in-depth understanding of what drives community trust in science, and how communication among decision- makers and community members can be tailored most effectively to increase the trust-building potential of research programs.

\section{Conclusions}

Overall, this study has demonstrated that scientific research can improve trust among decisionmakers and community members to support the governance of environmental resources. However, to ensure that the impact of scientific research in this regard is maximised, it is critical that scientific research programs place a strong emphasis on community outreach and engagement; i.e. via the establishment of citizen science projects and diverse communication strategies as part of the broader scientific efforts. It is also critical that communication and outreach efforts are implemented from the outset of scientific research programs and sustained following the completion of research programs, to ensure trust is not eroded over time. In doing so, the impacts of scientific research on environmental governance can extend beyond the provision of knowledge to inform decision-making processes, to also actively facilitate trust-building and participation among stakeholders that can enhance the long-term sustainability and conservation of marine resources.

\section{Acknowledgements}

We thank A. Kendrick for his guidance and input into the design of this study and efforts in facilitating this research. We also thank N. Marshall and S.K. Wilson for insightful discussions that improved the manuscript, and the anonymous reviewer who provided comments that improved the manuscript. Finally, we thank all participants who took part in the survey. Financial support was provided by the Western Australian Department of Biodiversity, Conservation and Attractions, the Western Australian Marine Science Institution and the Centre for Marine Socioecology at the University of Tasmania. 
Appendix A

See Figs. A1-A6
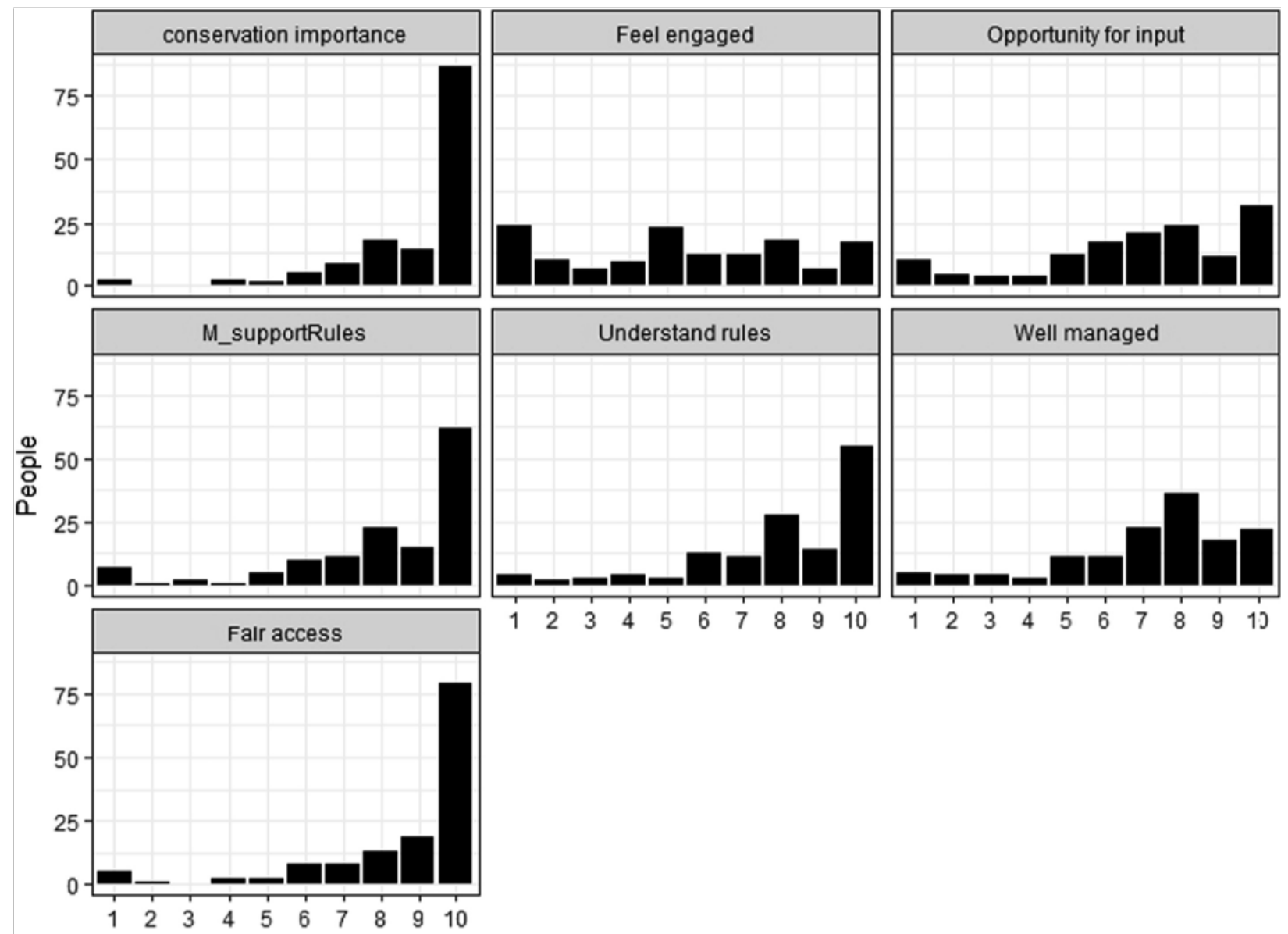

.




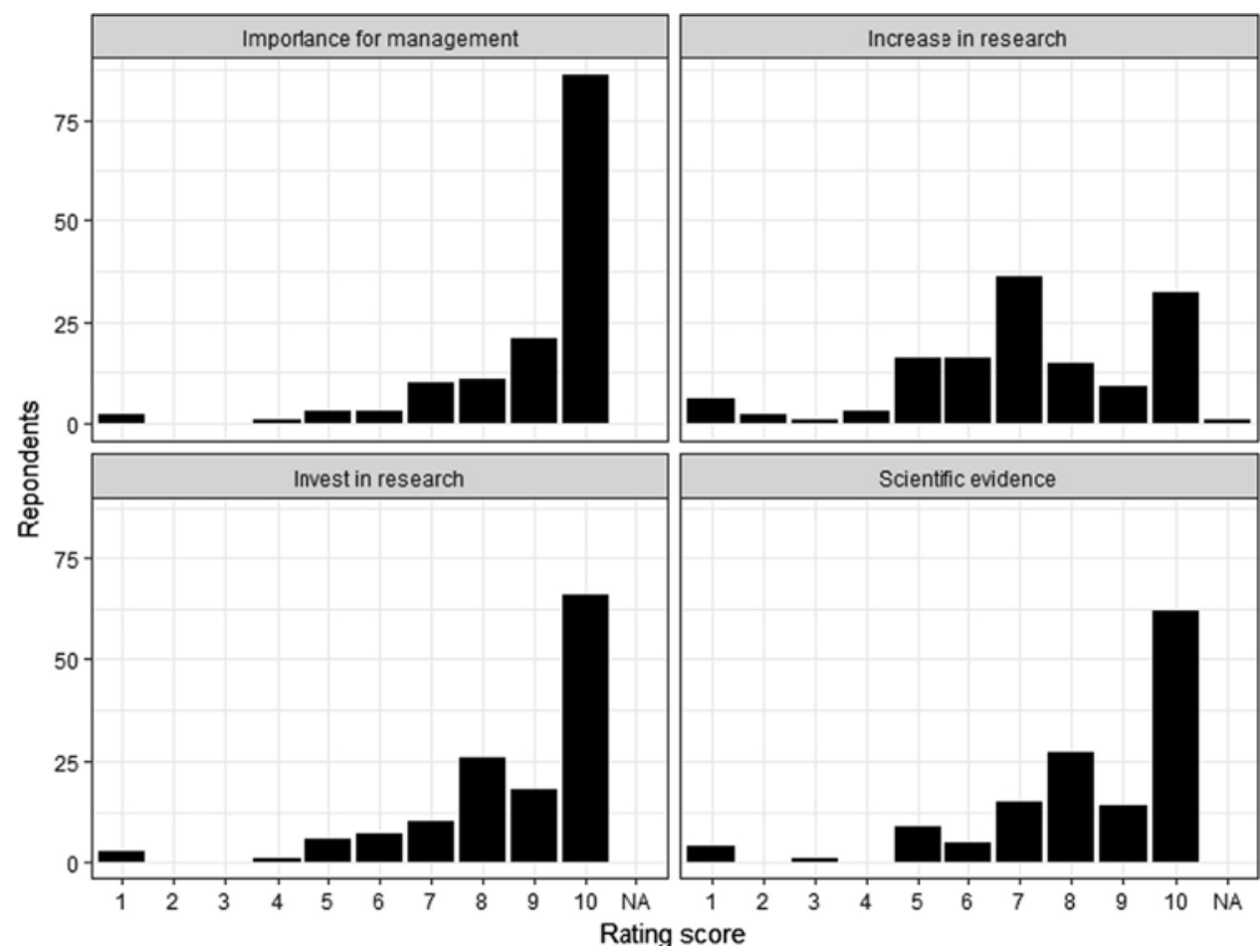

Fig. A2. Histograms for rating scores for questions related to perceptions of science. 


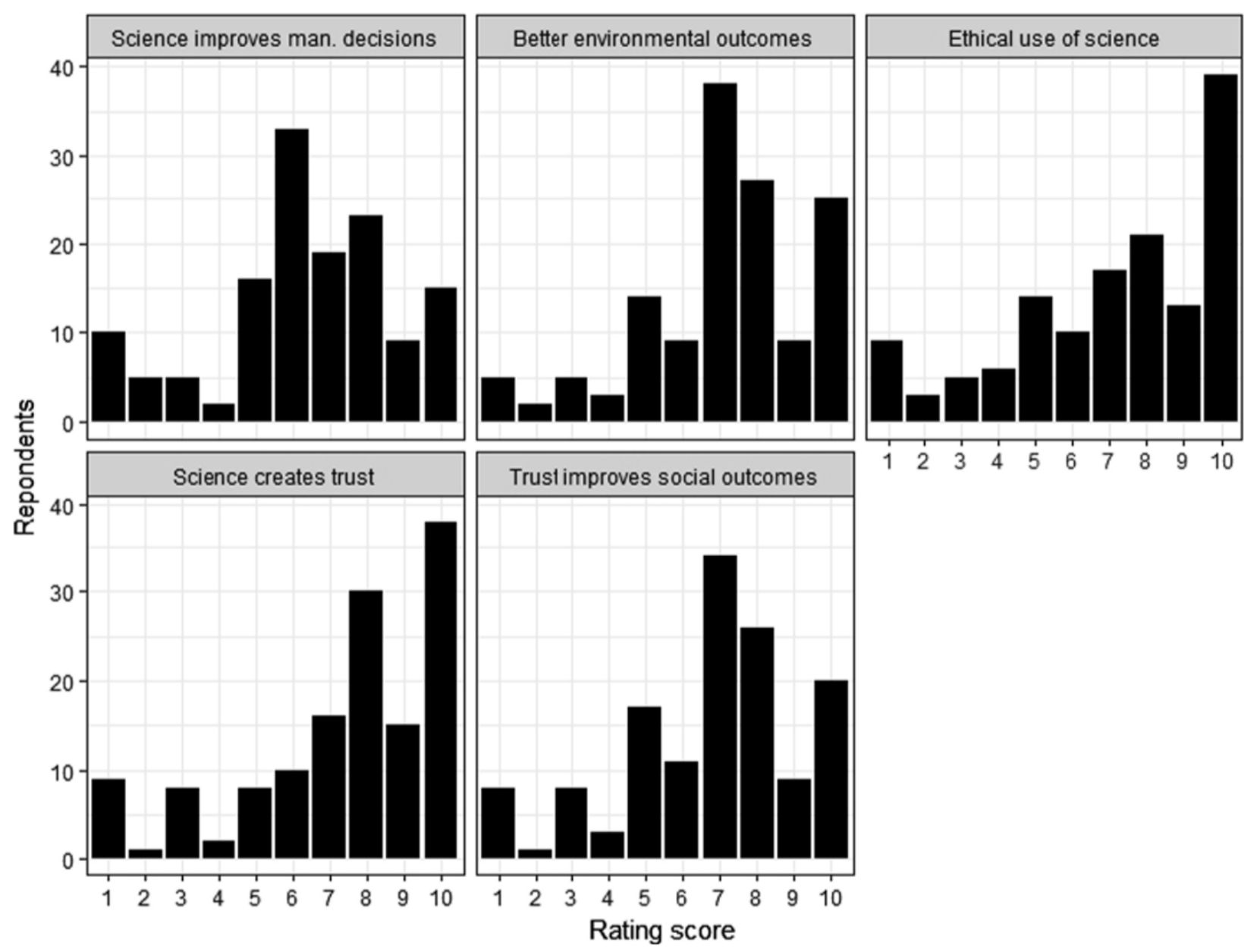

Fig. A3. Histograms for rating scores for questions related to trust. 


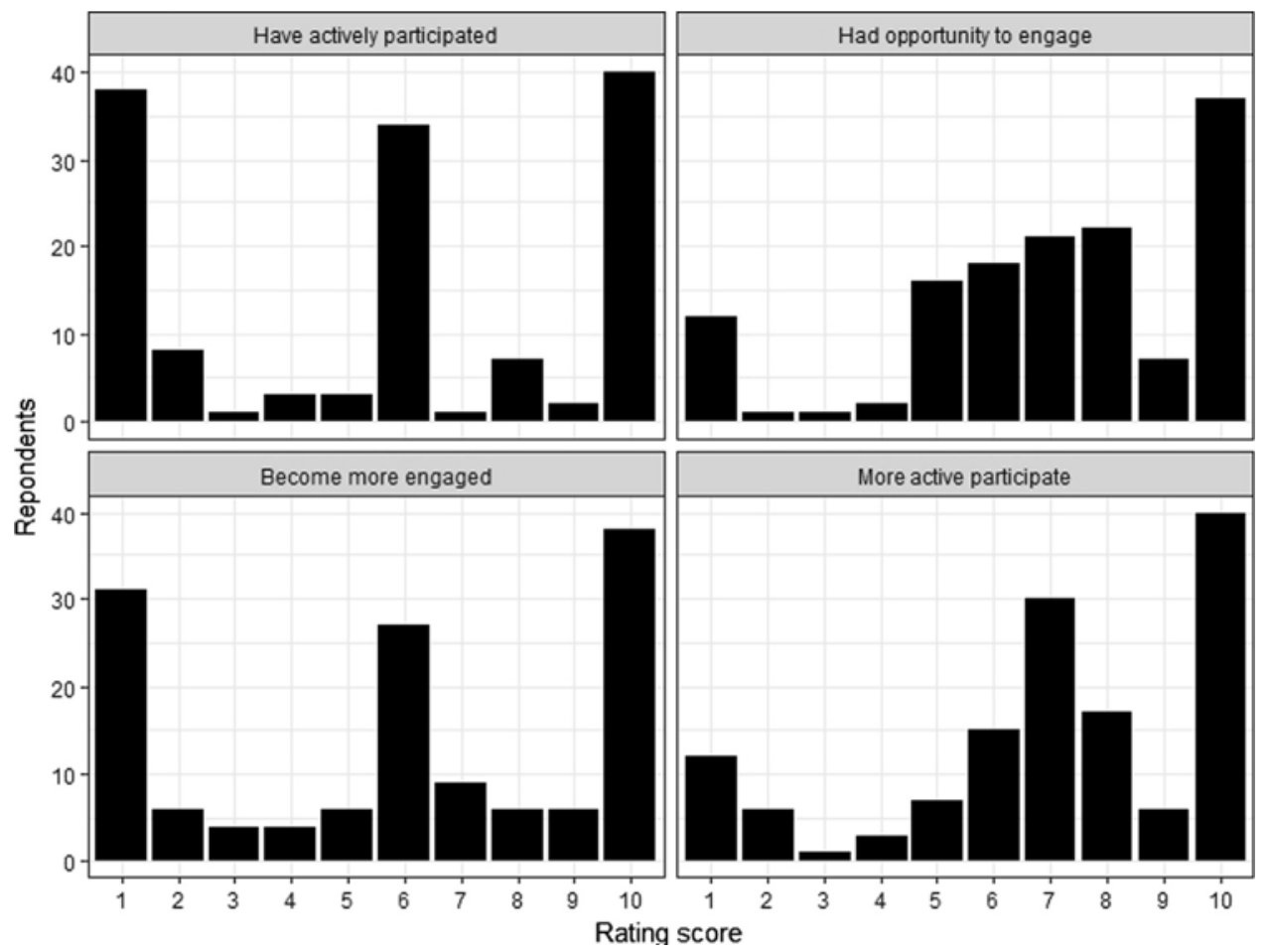

Fig. A4. Histograms for rating scores for questions related to collective action and cooperation. 

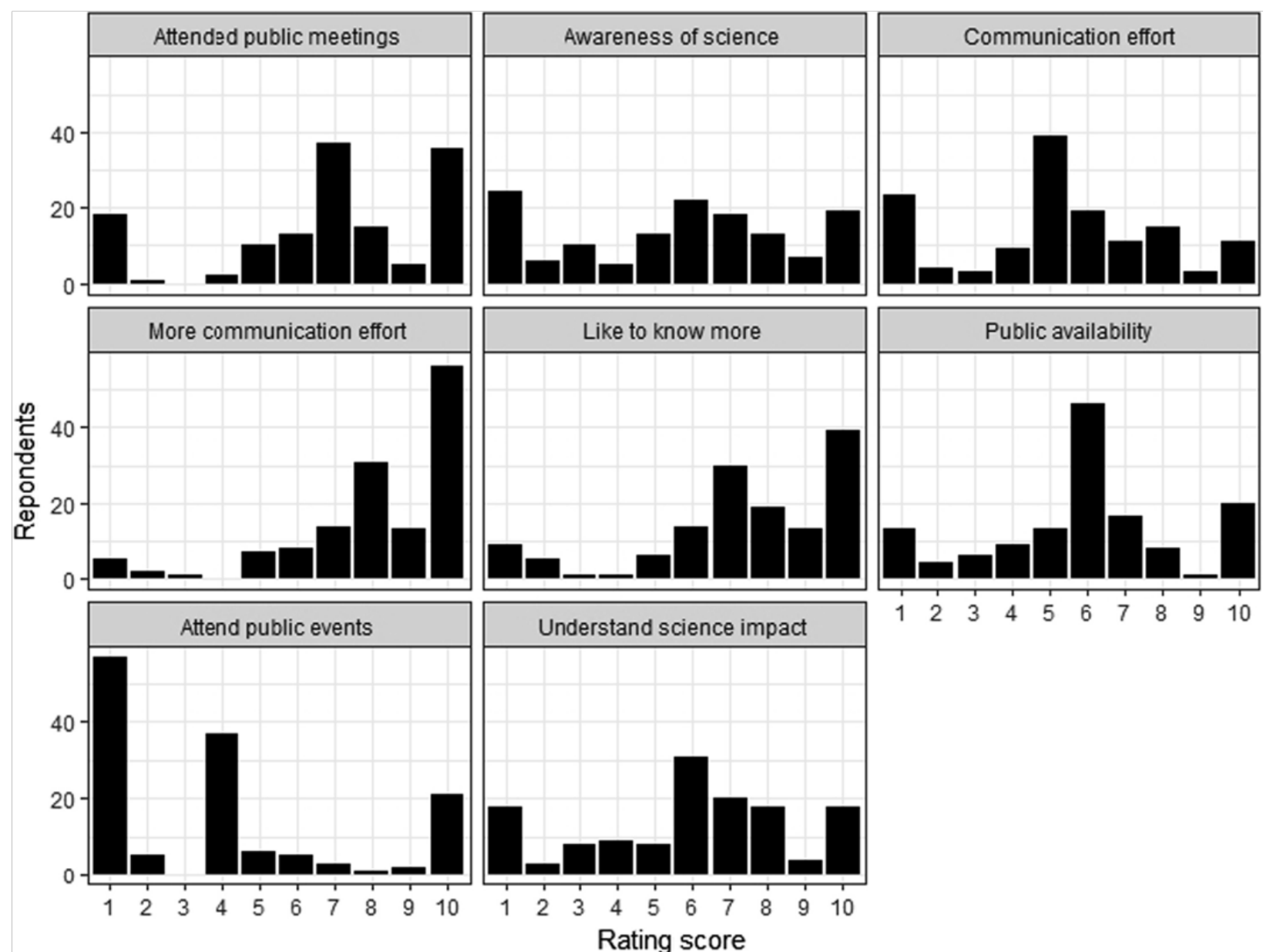

Fig. A5. Histograms for rating scores for questions related to information and communication. 


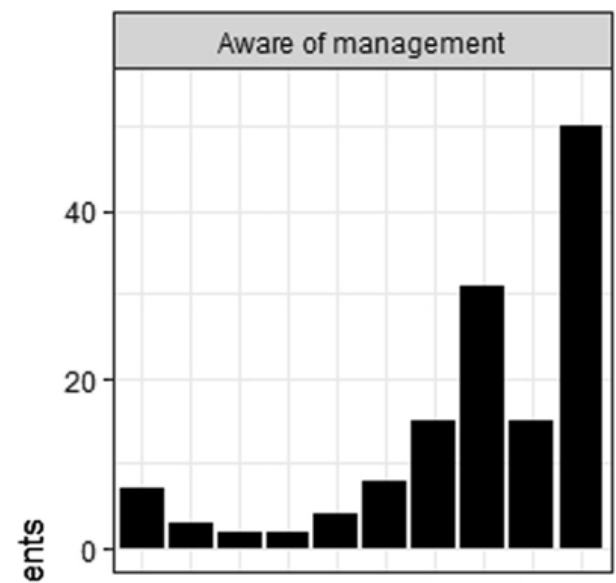

잉

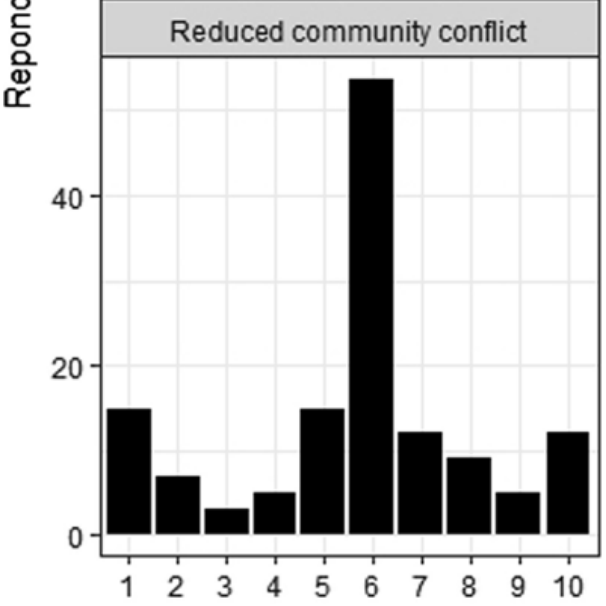

Fig. A6. Histograms for rating scores for questions related to social cohesion.

Rating score
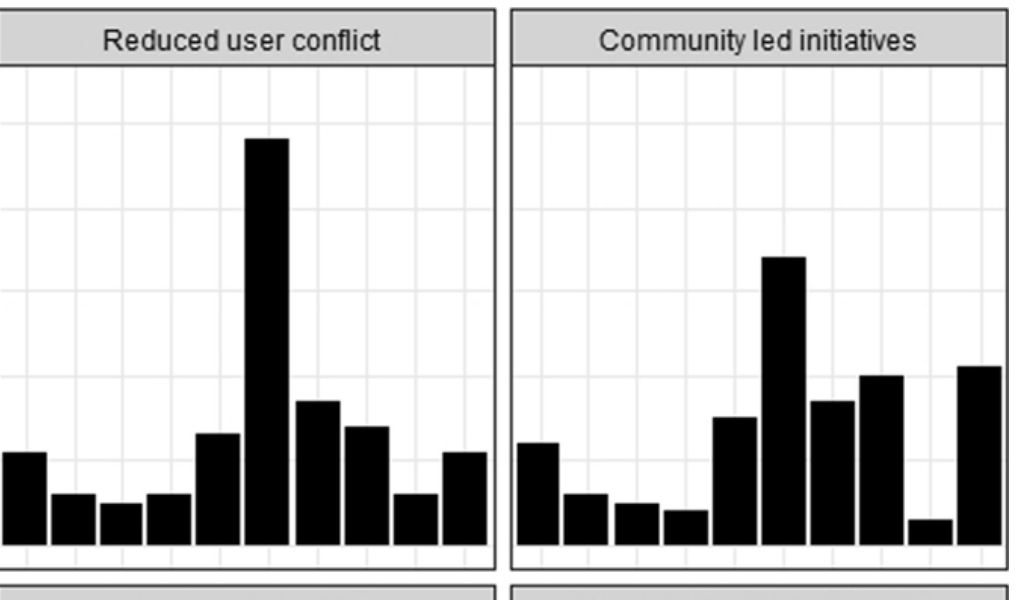

Stonger community relationship
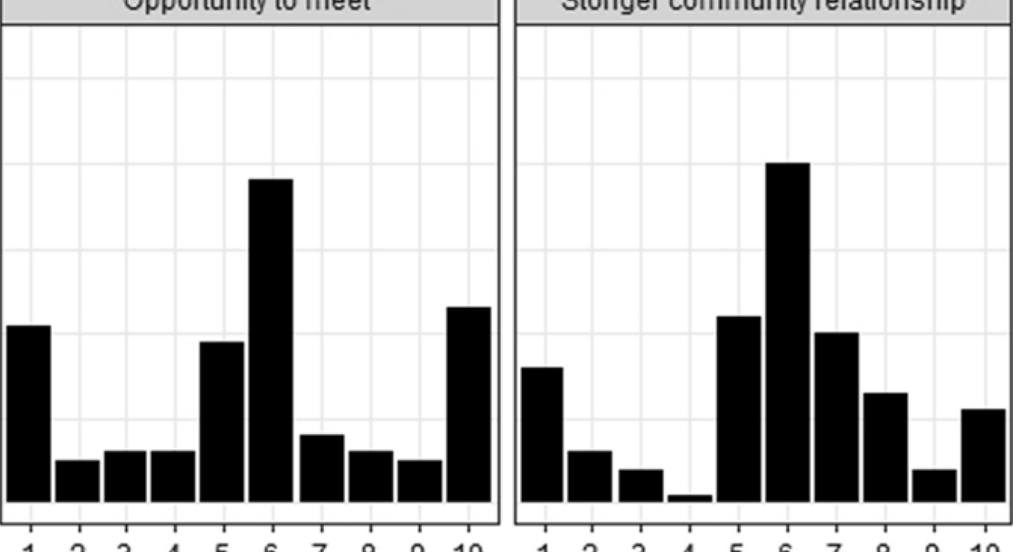

$\begin{array}{llllllllll}1 & 2 & 3 & 4 & 5 & 6 & 7 & 8 & 9 & 10\end{array}$ 


\section{References}

1. M. Anderson-Wilk, Changing the engines of change: natural resource conservation in the era of social media, J. Soil Water Conserv 64 (2009) 129A-131A.

2. G.S.M. Andrade, J.R. Rhodes, Protected areas and local communities: an inevitable partnership toward successful conservation strategies? Ecol. Soc. 17 (4) (2012) 14.

3. D. Armitage, F. Berkes, N. Doubleday (Eds.), Adaptive co-management: collaboration, learning, and multi-level governance. UBC Press, Vancouver, Canada, 2007.

4. S. Benartzi, J. Beshears, K.L. Milkman, C.R. Sunstein, R.H. Thaler, M. Shankar, W. Tucker-Ray, W.J. Congdon, S. Galing, Should Governments Invest More in Nudging? Psychol. Sci. 28 (2017) 1041-1055.

5. R. Bonney, T.B. Phillips, H.L. Ballard, J.W. Enck, Can citizen science enhance public understanding of science? Public Underst. Sci. 25 (2016) 2-16.

6. F. Boschetti, C. Cvitanovic, A. Fleming, E. Fulton, A call for empirically based guidelines for building trust among stakeholders in environmental sustainability projects, Sustain Sci. 11 (2016) 855-859.

7. J. Bouma, E. Bulte, D. van Soest, Trust and social capital: social capital and com- munity resource management, J. Environ. Econ. Manag 56 (2008) 155-166.

8. A. Bryman, Social Research Methods, Oxford University Press, Oxford, 2012.

9. S. Cornell, F. Berkhout, W. Tuinstra, J.D. Tàbara, J. Jäger, I. Chabay, B. de Wit, R. Langlais, D. Mills, P. Moll, I.M. Otto, A. Petersen, C. Pohl, L. van Kerkhoff, Opening up knowledge systems for better responses to global environmental change, Environ. Sci. Pol. 28 (2013) 60-70.

10. B. Cornwell, E.O. Laumann, L.P. Schumm, The social connectedness of older adults: a national profile, Am. Sociol. Rev. 73 (2008) 185-203.

11. C. Cvitanovic, N.A. Marshall, S.K. Wilson, K. Dobbs, A.J. Hobday, Perceptions of Australian marine protected area managers regarding the role, importance, and achievability of adaptation for managing the risks of climate change, Ecol. Soc. 19 (4) (2014) 33.

12. C. Cvitanovic, A.J. Hobday, L. van Kerkhoff, N.A. Marshall, Overcoming barriers to knowledge exchange for adaptive resource management; the perspectives of Australian marine scientists, Mar. Pol. 52 (2015) 38-44.

13. C. Cvitanovic, A.J. Hobday, J. McDonald, I. van Putten, K.L. Nash, Governing fisheries through the critical decade: the role and utility of polycentric systems, Rev. Fish. Biol. Fish. (2017), http://dx.doi.org/10.1007/s11160-017-9495-9.

14. C. Cvitanovic, S.K. Wilson, C.J. Fulton, G.R. Almany, P. Anderson, R.C. Babcock, N.C. Ban, R. Beedon, M. Beger, J. Cinner, K. Dobbs, L.S. Evans, A. Farnham, K. Friedman, K. Gale, W. Gladstone, Q. Grafton, N.A.J. Graham, S. Gudge, P. Harrison, T.H. Holmes, N. Johnstone, G.P. Jones, A. Jordan, A. Kendrick, C.J. Klein, L.R. Little, H. Malcolm, D. Morris, H.P. Possingham, J. Prescott, R.L. Pressey, G.A. Skilleter, C. Simpson, K. Waples, D. Wilson, D.H. Williamson, Critical research needs for managing coral reef marine protected areas: perspectives of academics and managers, J. Environ. Manag. 114 (2013) 84-91.

15. C. Cvitanovic, J. McDonald, A.J. Hobday, From science to action: principles for undertaking environmental research that enables knowledge exchange and evidence-based decision-making, J. Environ. Manag. 183 (2016) 864-874.

16. T. Dalton, Exploring participants' views of participatory coastal and marine re- source management processes, Coast Manag. 34 (2006) 351-367. 
17. F. Danielsen, N.D. Burgess, P.M. Jensen, K. Pirhofer-Walzl, Environmental monitoring: the scale and speed of implementation varies according to the degree of peoples involvement, J. Appl. Ecol. 47 (2010) 1166-1168.

18. J. Dawkins, Cooperate responsibility: the communication challenge, J. Comm. Manag. 9 (2005) 108-119.

19. A. Diedrich, N. Stoeckl, G.G. Gurney, M. Esparon, R. Pollnac, Social capital as a key determinant of perceived benefits of community-based marine protected areas, Conserv Biol. 31 (2) (2016) 311-321.

20. S. Du, C.B. Bhattacharya, S. Sen, Maximising business returns to corporate responsibility (CSR): the role of CSR communication, Int J. Manag. Rev. 12 (2010) 8-19.

21. C.J. Fombrun, N.A. Gardberg, M.L. Barnett, Opportunity platforms and safety nets: corporate

22. A. Freitag, M.J. Pfeffer, Process, not product: investigating recommendations for improving citizens science 'success', PLoS One 8 (5) (2013) e64079.

23. P. Gilmour, B. Coffey, K. O'Toole, Trust and knowledge exchange in coastal settings, Aust. J. Mar. Ocean Aff. 7 (1) (2015) 66-74.

24. D.C. Gledhill, A.J. Hobday, D.J. Welch, S. Sutton, M.J. Lansdell, M. Koopman, Jeloudev, A. Smith, P.R. Last, Collaborative approaches to accessing and utilising historical citizen science data: a case-study with spearfishers from eastern Australia, Mar. Fresh Res 66 (3) (2015) 195-201.

25. R. Göb, C. McCollin, M. Fernanda Ramalhoto, Ordinal methodology in the analysis of Likert scales, Qual. Quant. 41 (2007) 601-626.

26. A.J. Hobday, V.A. Doerr, N.A. Marshall, C. Cvitanovic, L. Lim-Camacho, Adapting to climate change: the role of organisational personalities in natural resource management, Reg. Environ. Chang (2017), http://dx.doi.org/10.1007/s10113-017-1227-0.

27. T. Hossain, J. List, The behaviouralist visits the factory: Increasing productivity using simple framing manipulations, Manag. Sci. 58 (2009) 2151-2167.

28. G. Hønneland, A model of compliance in fisheries: theoretical foundations and practical applications, Ocean Coast. 42 (1999) 699-716.

29. M. Hughes, T. Jones, I. Phau, Community perceptions of a World Heritage Nomination Process: the Ningaloo Coast region of Western Australia, Coast Manag. 44 (2016) 139-155.

30. M.F. Johnson, C. Hannah, L. Acton, R. Popovici, K.K. Karanth, E. Weinthal, Network environmentalism: citizen scientists as agents for environmental advocacy, Glob. Environ. Chang 29 (2014) 235-245.

31. J. Lacey, S.M. Howden, C. Cvitanovic, R. Colvin, Understanding and managing trust at the climate science policy interface, Nat. Clim. Chang 8 (2018) 22-28.

32. N.A. Marshall, R.C. Tobin, P.A. Marshall, M. Gooch, A. Hobday, Social vulnerability of marine resource users to extreme weather events, Ecosystems 16 (2013) 797-809.

33. V.Y. Martin, L. Christidis, G.T. Pecl, Public interest in marine citizen science: is there potential for growth? BioScience 8 (2016) 638-692.

34. B.J. McNeil, S.G. Pauker, H.R. Sox Jnr, A. Tversky, On the elicitation of preferences for alternative therapies, New Engl. J. Med. 306 (1982) 1259-1262.

35. K.L. Nash, C. Cvitanovic, E.A. Fulton, B.S. Halpern, E.J. Milner-Gulland, R.A. Watson, J.L. Blanchard, Planetary boundaries for a blue planet, Nat. Ecol. Evol. 1 (2017) 1625-1634.

36. A.V. Norström, M. Nyström, J.B. Jouffray, C. Folke, N.A.J. Graham, F. Moberg, P. Olsson, G.J. Williams, Guiding coral reef future in the Anthropocene, Front. Ecol. Environ. 14 (2016) 490498. 
37. R. Oda, Y. Kato, K. Hiraishi, The watching-eye effect on prosocial lying, Evol. Psychol. 13 (2015) $1-5$.

38. L.E. Ogden, Tags, blogs, tweets: Social media as science tool? Bioscience 62 (2013) 148.

39. J. Pretty, Social capital and the collective management of resources, Science 302 (2003) 19121914.

40. J. Pretty, H. Ward, Social capital and the environment, World Dev. 29 (2) (2001) 209-227.

41. N. Quinn, D. Holland, Culture and cognition, in: D. Holland, N. Quinn (Eds.), Cultural models in language and thought. Cambridge University Press, Cambridge, 1987.

42. R.L. Shaw, Enforcement and compliance in the Northeast groundfish fishery: perceptions of procedural justice in fishery management, the effects of regulatory methods, and prospects for compliance. Dissertation, University of Rhode Island, Kingston, Rhode Island, USA, 2005 (Available online at http://digitalcommons. uri.edu/dissertations/AAl3206256.)

43. J.L. Shirk, H.L. Ballard, C.C. Wilderman, T. Phillips, A. Wiggins, R. Jordan, E. McCallie, M. Minarchek, B.V. Lewenstein, M.E. Krasny, R. Bonney, Public participation in scientific research: a framework for deliberate design, Ecol. Soc. 17 (2) (2012) 29.

44. J. Shirk, R. Bonney, Informing a framework for citizen science within the US Fish and Wildlife Service. An independent science review conducted for the Consensus Building Institute on behalf of the US Institute, 2015.

45. R.L. Stephenson, A.J. Benson, K. Brooks, A. Charles, P. Degnbol, C.M. Dichmont, M. Kraan, S. Pascoe, S.D. Paul, A.R.M. Wiber, Practical steps toward integrating economic, social and institutional elements in fisheries policy and management, ICES J. Mar. Sci. 7 (2017) 1981-1989.

46. L. Stocker, D. Kennedy, Cultural models of the coast in Australia: towards sustainability, Coast Manag. 37 (2009) 387-404.

47. S. Stocklmayer, Engagement with science: models of science communication, in: J.K. Gilbert, S. StockImayer (Eds.), Communication and engagement with science and technology: Issues and dilemmas. Routledge, New York, 2013.

48. A.D. Thaler, K.A. Zelnio, A. Freitag, R. MacPherson, D. Shiffman, H. Bik, M.C. Goldstein, C. McClain, Digital environmentalism: tools and strategies for the evolving online ecosystem, in: D. Gallagher (Ed.), Environmental leadership: a reference handbook. Sage Publications, London, UK, 2012.

49. R.H. Thaler, C.R. Sunstein, Nudge: Improving Decisions about Health, Wealth, and Happiness, Yale University Press, 2008 (ISBN 978-0-14-311526-7. OCLC 791403664).

50. R. Thompson, Cultural models and shoreline social conflict, Coast Manag. 35 (2007) 211-237.

51. M. Thompson, R. Ellis, A. Wildavsky, Cultural Theory, Routledge, 1990.

52. R.A. Turner, J. Addison, A. Aria, B.J. Bergseth, N.A. Marshall, T.H. Morrison, R.C. Tobin, Trust, confidence, and equity affect the legitimacy of natural resource governance, Ecol. Soc. 21 (3) (2016) 18.

53. T.R. Tyler, Psychological perspectives on legitimacy and legitimation, Ann. Rev. Psychol. 57 (2006) 375-400.

54. S. Vann-Sander, J. Clifton, E. Harvery, Can citizen science work? Perception of the role and utility of citizen science in a marine policy and management context, Mar. Pol. 72 (2016) 82-93.

55. A.U. Whiting, Consolidation of the Ningaloo Turtle Program: Development of a statistically robust and cost efficient survey design. Report to the Ningaloo Turtle Program, 51pp, 2008. 